\title{
OBJECTIVES OF FEDERAL CRIMINAL PROCEDURAL REVISION
}

\author{
JEROME HALL $\uparrow$
}

CrImINal procedure is a microcosm of universal significance. It is the repository of present understanding of serious controversy-solving as well as the promise of any enduring solution of major conflict in any field whatever. For in the procedure of criminal law, we read the history of man's halting circuitous ascent from resort to vengeful feud and sheer annihilation to that of peaceful and intelligent adjudication. To appreciate both the conceit and the solemnity of such endeavor, one must recall, also, the long history of superstitious reliance on chance as well as that of dependence upon the Oracle or other authority. The almost unimaginable advance represented in modern criminal procedure has not meant progress merely of professionals. Criminal procedure is a community's way of life in its areas of greatest stress. If rational settlement is possible here, where emotion and instinctual drive beat hardest upon restraint and intelligence, it should be possible in every field of human conduct. Hence the current undertaking for revision of federal criminal procedure, though it demands the nicest of technician's skill, in its wider significance challenges American scholarship to understand its basic complex nature and the ramifications of its sucial as well as its legal functions.

The current project calls for "revision", and "revision" may be assumed to mean not merely change, but reform, i.c., change in desirable directions. The premise is that such change is possible, that we are not simply indulging in pious hopes. At the same time, the history of procedural reform should dissipate any lingering naive optimism in this regard. In very recent years, c.g., in states which have adopted new codes of criminal procedure, courts have nullified some of the most important reforms (such as the requirement to object to defects in an indictment before trial) by reversion to the prior decisions. The long tradition of present procedure, the deep imprint of professional methods, and most of all, the existing range of thought and evaluation, all impose rigorous limitations on actual deliberate change as distinguished from talking about it or enacting new rules. Nonetheless it is a persuasive hypothesis that there are wide and important areas in procedure suscepti-

† Professor of Law, Indiana University Law Sehwol. Author of TuErT, Law A:BD Society (1935), Reanngs in JuRisprudence (Ed. 1938), and various articles in legal and social science periodicals. 
ble to modification over a period of time by well considered programs of reform.

To discover these areas and to institute such programs, criminal procedure must be understood as an integral phase of what is rather euphemistically called "the administration of criminal justice." Viewed in the large, what is presented to our analysis is an organization of ideas implemented by methods designed to their realization. This totality is usually divided into substance, procedure, and practice (discretion), but without considering any differentiae at this time, we may note that procedure and substance have to do with explicitly stated prescriptions, and that "practice" (e.g., the choice of personnel, the organization of a state's attorney's office, the waiver of felony charges, the keeping of records) is concerned with judgment not closely directed by such rules. What needs to be stressed is the mutual dependence of one upon the other, and the inevitable adaptation of each of the above three divisions of criminal justice to the conditions and changes in the other. Thus, it is well established that if the substantive laws are unduly severe, indictments will be gone over with the finest of combs - technicalities abound. The social effects of penal laws are accordingly influenced considerably by crininal procedure. If police are incompetent, the legislators rush in to stem the crime wave - by enacting substantive laws, just as both police and prosecutors are discouraged in their diligence if known offenders slip through a maze of artificial refinements in the procedure. It is evident that natural temptations to extend the import of procedure and of any specialized analyses must be restrained, but the relationship of procedure to the other chief elements in the total process can be investigated, and the particular problems arising from such interdependence at least formulated.

\section{Logical Functions and Objectives}

The present project for revision of federal criminal procedure has possibilities of such range and significance that the problem challenges not only to a consideration of special and immediate difficulties and objectives but, even more, to an examination of the basic functions and ends of any rational system of criminal procedure. In fact, both types of problems are closely integrated.

Objectives of revision must build on the objectives of criminal procedure; "objectives" transcend "functions" though they are sometimes similarly formulated; discovery of the former depends on knowledge of the latter - these are the initial elementary premises of our analysis.

Professionals sometimes give the appearance of believing that procedure was created for their special interests, not least to provide the entertainment of a fascinating play - in which trait, they do not differ 
markedly from other human beings. Hence a first obvious observation as to both functions and objectives is that criminal procedure is also a sort of public utility which at least purports to provide better service in direct proportion to its rationality. To characterize any method as "rational" is, firstly, to assert that people can and do think, secondly; that it makes a great difference whether they think or employ some other method of discovery, and, thirdly, that the method employed is designed to facilitate the discovery of truth, rather than retard it. It is necessary to stress the fact that criminal procedure is a method of discovery, not one of demonstration of accepted truths. To comprehend the rational function of procedure it is essential to keep in mind that we start not with answers but with questions, that the entire apparatus is defensible and intelligible only on the premise that we seek answers which we initially do not possess, and that we seek the best answers possible. It is apparent, also, that procedure can be logical even though the substantive law is unjust or irrational. That is to say, procedure discharges certain logical functions, the results of which are not necessarily desirable. As Aristotle put it, "What makes a man a 'sophist' is not his faculty, but his moral purpose." 1 But whatever the justice of the ultimate decisions, rational procedure provides the best instruments for discovery of the necessary answers.

The substantive criminal law determines the kind of questions we must ask; rational procedure, enbodying logical principles, prescribes what steps we must take and how we shall take them to secure the necessary answers. The general descriptions of fact included in the substantive law, known as the hypotheses or behavior-circumstances elements, fix the ultimate targets. Criminal procedure is designed to apply these general norms to particular cases, and the steps leading to such concretization have been variously described. From the riewpoint of tutal administration, these are the discovery, apprehension, prosecution, conviction and treatment of criminals. From the procedural viewpoint these terms are inappropriate. Here our concern is with the intellectual (and authoritative) process of securing answers to the questions raised in light of the substantive criminal law. The steps requisite to such decision are a trial, presupposing correct methods have secured the attention of a court, formulation of the issues fixed by the substantive law, the introduction of evidential data before a court which must decide one way or the other, and the entry of judgment accordingly. Thus the rules of procedure for the most part govern a particular kind of debate - one that differs rather in the potentiality of practical effects than in any essential of argument generally.

The presence of the defendant is not necessary to the conduct of the argument, however fair it may be to provide opportunity to attend. For-

1. Aristotle, Rhetorrca, Bk. I. i. 14. 
mulation of issues is the initial logical requisitc. If we keep in mind the nature of the inquiry as indicated above, we can evaluate overly-ambitiots schemes to "simplify" pleading that border on its total abolition. If a trial is to be had it must be relevant to issues that are nccessarily raised; "notice" pleading does not in the slightest degree modify the logical conditions of rational procedure. Notice pleading is a significant possible method of eliminating unnecessary technicality and delay. It contains no magic that can dispense with the necessity of formulating issues. Morcover, it seems clear that in federal criminal procedure especially, but largely, also, in the states, many major evils of technical pleading have practically disappeared because of general insistence on substantial damage $;{ }^{2}$ hence recitation of the exorbitant meticulosity of the past century is simply irrelevant. In addition, there is reason to believe that bills of particulars would handicap prosecution whereas reasonably detailed pleading does not. Accordingly the indicated direction for reform is informal pleading and modern vocabulary.

Simple terms can be employed to symbolize the various elements in offenses which need not be pleaded; certainly there is no reason to cling to the ritual of traditional verbiage that enshrouds them. Indeed, to ant unconditioned mind, traditional common law pleading must seem a museum-piece, a bizarre logomachy, a device to extract issues "like the roots of an equation." 3 Little overstatement is Holmes' remark on "the inability of the 17 th century common law to accept a pleading that did not exclude every misinterpretation capable of occurring to an intelligence fired with a desire to pervert." 4 But we must not permit peculiarity of language and excess of technicality to conceal the essential ends that such pleading served in the formulation of issues. We may condemn the extremes to which rigorous insistence on singularity and certainty led (although a fair interpretation of administration of the severe 17th century penal law might suggest that technicality had significance and value) but "avoidance of obscurity and confusion, of prolixity and delay" " are certainly high desiderata in any rational procedure. The indictment serves not only to frame issues by stating material facts clearly but it serves at the same time to warn the defendant and permit him fair opportunity to prepare his defense and, also, to avoid double jeopardy. It is necessary to discover excessive technicality and rigidity and to eliminate them; it is possible to frame the issues by instruments or even oral proceedings that we do not call "pleadings"; so, too, other pro-

2. See Missouri Crime Survey (1926) 249; Hakno, Illinots Chtake Sunvey (1929) 185.

3. Warren, Law Studies 208, quoted by Stephen, Prtnciples of Pleading (Andrews' ed. 1901) 16.

4. Paraiso v. United States, 207 U. S. 368,372 (1907).

5. Stephen, Principles of Pleading (Andrews' ed. 1901) 262. 
vision can be made for avoidance of double jeopardy. Formal innovations are arailable, but it will be difficult to make actual gains in these directions beyond that provided for in recent codes; we shall assuredly fail to do so if we lose sight of the irreducible requirements of rational trial. We must remember, finally, that instead of the rampant irresponsibility that characterized pleading in civil litigation, in the criminal law: there have been supervision and check by grand jury, public prosecutor and preliminary hearing.

The issues, however formulated, must consist of contradictory assertions regarding the material facts. Two types of questions are involved: do the facts charged fall within the behavior-circumstances of any specific penal law, and secondly, did the facts charged actually occur? It will be agreed that fact-finding and law-finding should proceed in an orderly manner, designed to secure the distinctive necessary answers to the material questions. The argument must be advanced, and the rules of procedure must accordingly reflect the logical requirements of such controversy, e.g., as to who must begin, what is the burden of proof and the like. In addition, there must be rules of convenience, such as the time of beginning, the length of argument, etc. There must be rules of decorum, e.g., both parties should not speak simultancuusly, and in a courtroom, the prestige of the judicial institution suggests appropriate forms of address. Facts relevant to the issues must be intruduced and these data must be interpreted and evaluated. Accordingly, it will be seen that the law of procedure incorporates principles of organization, of logic and empirical knowledge, of convenience and decorum, and of policy.

Criticism of procedure must be in terms of objectives and in terms of present means of their implementation. What needs discovery and careful formulation is a series of cogent standards to serve as bases for evaluation. ${ }^{6}$ The literature of criticism of criminal justice is voluminuus and it is not easy to ascertain the implicit criteria employed. This liternture may conveniently be divided into the following general types: first, that concerned with the process of procedure from an internal or logical viewpoint; secondly, that based on political-ethical viewpoints. Empliasis is on the certainty of recognized methods of procedure and the value of this for stability, the restraint imposed on officials, not least on their cupidity and ignorance, the value of uniformity; most of such evaluation is applicable to substantive law as well. Finally, there is a considerable literature written from a practical, administrative viewpoint; criticism is in terms of delay, cost, efficiency, and the like, e.g., the crime surveys. From the description above of the rules included in procedure, it is

6. See 2 Bexthas, Works (Euwring's ed. 1\$43) 17; 2 Lwiveston, Conmuxt Works on Criminal JuRisprudence (1873) 186-87. 
apparent that criticism and standards must be formulated accordingly, in light of the variety of types of rules, their respective functions and objectives. The range of possible criticism is no less than that of logic, science, ethics and sound judgment in the conduct of practical' affairs.

\section{The Basic Dilemana of Criminal Procedure}

None of the above sources, forms or standards of criticism has any relevance or utility apart from the ultimate ends of criminal procedure - to convict the guilty and acquit the innocent. Only in the light of this distinctive dual objective of criminal procedure can any intelligent judgment be made as to the logical, scientific, ethical or efficient quality of any method, proposal or reform. Hence the most important single generalization that can be made about American criminal procedure or for that matter about any civilized criminal procedure is that its ultimate ends are dual and conflicting. It must be designed from inception to end, to acquit the innocent as readily, at least, as to convict the guilty. This presents the inescapable dilemma of criminal procedure which Bentham failed to recognize. For a procedure that does not asstume guilt, but seeks to determine it rationally, by its basic hypothesis provides for innocence.

The dilemma consists in the fact that the easier it is made to prove guilt, the more difficult does it become to establish innocence. Laick of appreciation of the dual character of our criminal procedurc is apparent in much of the criminological reform movement in the recent past which reflects hardly any suspicion that police and prosecutors are not omniscient. The presumption that to be charged means to be guilty has been tenaciously, if unconsciously, entertained by well-intentioned reformers lulled into complacency by humanitarian motives to stubstitute "treatment" for purishment, and enlightened by negligible insight into the functions of criminal procedure. It can be demonstrated that their agitation parallels Enrico Ferri's almost to the word; one has but to read his condemnation of any presumption of innocence and of civil liberties generally to know where such reform leads. ${ }^{7}$ The problem is of paramount importance because of the challenge to elementary democratic values embodied in the Constitution and the Bill of Rights largely a document of criminal procedure, and because, in conjunction with the guarantees of the written instrument, criminal law and procedure provide the most perfected inclusive safeguard against oppression available. The danger here is especially great because most of the com-

7. FerRi, Criminal Sociology (Kelly \& Lisle's trans. 1917) 445-46. Compare Hall, Nulla Poena Sine Lege (1937) 47 Yale L. J. 182-85, 189; Criminal Attcmpt-A Study of Foundations of Criminal Liability (1940) 49 id. at 829-31; Prolcyomena to a Science of Criminal Law (1941) 89 U. of PA. L. REv. 570-75. 
petent members of the bar are so utterly uninformed in this branch of the law that the lawyers' criticism that can normally be expected concerning importànt proposed legal changes is non-existent.

Failure to appreciate the dual nature of American criminal procedure is represented in a number of fallacies. The degree of error in the fallacy that indictment means guilt is not reduced by the fact that the police are honest and competent and that the probabilities are therefore great that the accused committed the crimes charged against them. Admittedly, under such conditions a generous and circumspect attitude is required to give the presumption of innocence effect. Admittedly, also, the presumption of innocence does not rest solely on ethical principle; it equally represents stability of institutions, public confidence and the probability that most guilty persons are convicted. But the overriding considerations are that reliance is on rational procedure to determine guilt or innocence, and that, whatever police competence and the statistics suggest, we cannot form any intelligent judgment on this basis with reference to any particular case. Statistical generalizations hold true only for large numbers; even if $99 \%$ of all persons charged were convicted, this should not make the slightest difference in the judging of any particular case. ${ }^{8}$ A scientific dictator might "liquidate" all persons accused by secret police in camera without compunction though he were confident the police were in error in many cases. If we cleave to the ethics of civilized peoples, we must reject statistics, or rather use them where they function, and protect each individual accused person by traditional safeguards and recognized canons of fairness.

Related to the above fallacy is much of the criticism dramatized by "mortality" tables which, analogizing from mechanics, applies engineering principles of "efficiency" in disregard of the more persuasive, relevant explanation that insufficient evidence warranted nolle prosequi, dismissal or acquittal.

Thirdly, there is the fallacy of arguing that because the accused had so few rights in the 16th and 17th centuries, therefore he has too many rights now. This view is not norel, and Stephen writing in 1863 noted that "one of the commonest arguments against allowing prisoners to be defended by counsel always was, that rogues had too many chances of escape already." 9 The present form of this argument points to the fact that until about 1700 an accused person could not testify in his own behalf, be represented by counsel, have access to books, have a copy of

S. In reversing a conviction because the trial judge had instructed that " $a$ man of the abandoned character of the prisoner has not the presumption of innocence in his favor," it was held "The presumption of innocence applies to every person charged with a criminal offense in precisely the same way ..." Slater v. H. M. Adroate, 1928 Scots L. T. 602, 606.

9. A General View of the Criarinal Law of England (1863) 175. 
the indictment or other means of knowing the charge or the witnesses who would testify against him. There were few restrictions on the evidence that could be used against him; he could not call sworn witnesses in his behalf. The trials were extraordinarily efficient, "never extending beyond a day." 10 It may be wise to place certain restrictions on the present mode of criminal defense but it is obviously fallacious to pretend that the necessity or wisdom results because the pendulum has swung too far already in favor of the accused. We know that under present safeguards, innocent persons are convicted, and the recent federal provision for compensation ${ }^{11}$ implies that their number is not negligible. Anyone with actual experience in the administration of criminal law realizes that in the vast majority of cases the handicaps of fortune and intelligence are so great as to make "equality" of the parties hardly more than a humbug. The professional criminal undoubtedly has many advantages but they result from his greater knowledge, financial and political support, as well as from deficiencies in the substantive law. There is wisdom in the observation that the substantive criminal law should be designed for criminals, the procedural for honest people. Certainly any revision in criminal procedure constructed with professional offenders particularly in mind, or on the supposition that "the rogues have too many chances of escape" because of the 18th and 19th century progress in safeguards, would result in a ritual whose efficiency would be equalled only by its terror.

There is fourthly, the fallacy fetchingly described as "protection of society against criminals." Group security is opposed to individual liberty, with the clear implication that we must choose between them. This separation of group from individual, of society from offender, is one of the most vicious fallacies ever invented. Again it begins with the presumption of guilt. It implies that any method of "social defense" is permissible after one has been thus prejudged, and that any measures of "prevention" are proper. Society is composed of individuals, but the logic of the above authoritarian ideology would place every individual outside the pale - should the occasion, as created by the logicians in political control, arise. As a matter of fact, group security is a function of individual security. If criminal procedure is designed to facilitate convictions, public security is imperilled. Pro tanto does "protection of society" increase when each individual. is protected from indiscrintinate and irrational exercise of official power. We may recognize that "society" denotes a being different from the total number of its units, separated one from the other, and realize at the same time, that "socicty" and "individual" merely designate aspects of human nature, not any actual

10. Allees, Legal Duties (1931) 269.

11. 52 Strut. 438 (1938), 18 U. S. C. $\$ 729$ (1940). 
antithesis. Though elaboration of the above thesis cannot be undertaken here, it may still be urged that even if the above dichotomy of "society" vs. "individual" be adopted as actual, a Revision Committee might well ponder on the fact that federal prosecutions under present procedure result in a remarkably high percentage of convictions.

All of the above fallacies result from failure to comprehend the inmanent conflicting ends of any civilized criminal procedure. This duality of objectives can be expressed mathematically, and it should be possible to construct a calculus of the probabilities of decision as functions of the conditions of trial, present or proposed; the range of variables wotuld be complete abandonment of any prosecution for criminal behavior, on the one extreme, to treating every complaint as equivalent to conviction, on the other. In the absence of a forensic sociology, such objectivity would be hypothetical, but such a deliberate exercise would accentuate the implications of the basic axiom of criminal procedure. It might even provide the bare outlines of a future empirical science of procedure. Fortunately there is little likelihood of any present drastic curtailment of the basic guarantees of the Constitution and Bill of Rights. What lies closer at hand is the possible ignoring of the nicer ramifications of the above principles, the temptation to remedy substantive defects by procedural reforms, and to compensate for incompetent administration, e.g., in prosecution, by loading additional burdens on the accused, or in sentencing, by radical curtailment of judicial functions.

Such motivation is rarely perceived; the refurms are advanced under the aegis of logic and science. Thus, as to sentencing by "experts", majority verdict, and notice of a plea of alibi or of insanity. It is impossible to discuss these proposals here but there are relevant factual considerations that may be briefly indicated. As to alibi, it is apparent that the need for notice by the prosecutor has been grossly exaggerated. ${ }^{12}$ Any competent prosecutor anticipates defenses, and in certain crimes alibi is commonplace. Besides, aid to prosecution is problematic in some jurisdictions where alibi notice is required, because courts are then prone to restrict the proof to the precise day on which the crime is alleged to have occurred. There is greater reason for requiring notice of insanity since this defense is relatively rare and, also, requires considerable special preparation to meet.

But the major consideration that gives pause to the wholesale adoption of reforms designed to facilitate conviction results from a judgment on the total situation, one that is characterized normally by a powerful state with practically unlimited resources arrayed against an impotent individual. Hence a great many informed persons, who would readily

12. Compare Stayton \& Watkins, Is Specific Notice of the Defonse of Alibi Desirable? (1940) 18 TEx. L. REv. 151. 
concede the abstract fairness of many reforms if the parties were evenly matched, are loath to increase the resources of an already vastly superior litigant. Thus with reference to the apparently desirable extension of depositions, it is clear that unless accused persons are in fact enabled to be present and to take depositions, the reform aids the state only. Accordingly it is insisted that even such neutral reforms must be judged in light of the facts relevant to their actual administration. The diffictlty is that the poor, the ignorant and the impotent hardly ever get their needs understood, much less, fully provided for. One of the most generously motivated measures in recent years, the public defender, illustrates the impasse. The statistics on the increased pleas of guilty and on huge "savings to the taxpayers"13 reveal only too clearly that, at best, the plan represents a lesser of existing evils. Perhaps the most that can be hoped for is that a sympathetic understanding of actual conditions will temper paper plans for relentless application of logic to criminal procedure.

\section{Other Limitations on the Application of Scientrific Methods in Criminal Procedure}

Certainly sound revision will employ logic to discard useless ritual and advance rational procedure. Certainly such revision must employ all relevant science and scientific method, e.g., in analysis of the rules of evidence. But revision will not only miss its mark, it will be positively harmful if it does not subject each proposal to analysis in light of the basic duality of criminal procedure, in effect, if it does not weigh the ethical import of any proposed measure of reform, and do so in full awareness of the actualities that determine the outcome of criminal prosecutions. The formula is simple: logic and science must be limited by policy; but the application is difficult and calls for the nicest integration of experience in actual criminal administration with the subtlest comprehension of the ethical implications of criminal procedure. Under such conditions and with such objectives, revision will frequently eschew science for less effective methods. The existing preference is apparent when we consider that a criminal trial turns almost exclusively on human testimony. Homo sapiens talks and there is accordingly available the best possible evidence of human conduct - communication by the actor. Hence the insistence of the mediaeval inquisitor upon "confession or else" was no less logical and scientific than grim. In our books and in the courts, we abjure torture (though the police are not always so unscientific!); in effect, we even tell suspects not to talk because their statements will be held against them. We have constitutional gutarantees

13. See Goldman, Economies Effected by Public Defender Plan (1939) 23 J. Ax. Jud. Soc. 63, and recent reports from the office of the Public Defender of Cook County. 
against self-incrimination; we make some sincere effort to provide counsel to guard against indiscretions. All of this is illogical in the extreme, considering that disclosure by the defendant would be the simplest, the cheapest and very frequently the best evidence of what we seek to know. The point here is not that we must accept every existing limitation on trial methods as an absolute value - for example, it is at least debatable whether comment on the defendant's failure to testify should not be permitted - but that we must recognize as fully as possible that we do impose such limitations, and that each involves a basic question of policy that operates directly contra the relevant logic.

There are other considerations regarding the application of scientific methods in criminal procedure. Indeed the most perplexing of all problems of legal reform is presented by demands for total logicality, for such a streamlining of procedure as to extract completely the game, the drama, the battle. Insistence on business efficiency, total condemnation of the jury, appeals for decision by experts and for scientific investigation as opposed to "trial by battle" are the familiar proposals. Their initial persuasiveness cannot be denied; but their relevance to and utility for criminal trials must be carefully weighed nonetheless. It is submitted that criminal procedure serves other functions than purely logical and scientific decision; that, indeed, in light of the facts, there are and, for an unforseeable future, will continue to be, sharp limits on the availability and utility of scientific methods in criminal procedure. The argument in support cannot be elaborated here but the outlines of the thesis must be briefly indicated.

Criminal law is people's law in a sense that applies to no other department of law. Indeed, for most persons criminal law is the only very familiar law because of almost daily actual and vicarious participation in its process. Most persons may know little of the technicality of either substantive or procedural law, but they can follow the rational outline of the conduct of the trial; a sense of security results that could never be provided by an expert operating in secret chambers or by little known formulas. ${ }^{14}$ Hence criminal procedure constitutes a social situation which finds little counterpart in the administration of complicated property interests or other relatively impersonal affairs. Certainly the differentiation of such matters from more simple human rights, intuitively understood in the light of our history of civil liberties, supplies one clue to the recent direction of important judicial decisions. Beyond popular understanding of and participation in the processes of criminal law, there are other reasons for questioning the unmitigated application of science and scientific methods to criminal procedure. The criminal law in large measure represents an intimate self-government. The supplanting

14. Compare Beccaria, Essay on Crimes and Punishurents (3d ed. 1770) 53, 55. 
of popular institutions, especially those productive of confidence against abuse, with government by scientists would challenge public opinion, especially if effected by the recommendations of persons appointed by officials who were themselves appointees. We must recognize that the axioms of self-government and the democratic process imply that the best methods may temporarily, at least, be rejected although it is certainly defensible to maintain that in the long run social problems are best solved by consensuses freely arrived at rather than by imposition - even by disinterested specialists.

Finally, it is evident, also, that criminal procedure discharges nonrational functions which cannot presently be ignored. The thesis in this regard may be stated somewhat paradoxically: it is rational to employ criminal procedure, in part, to satisfy non-rational needs. The confidence aroused by the order, publicity and rationality of criminal procedure lias been noted. But there are even deeper instinctual needs that cannot soon be modified. No reform of criminal procedure may lightly ignore the public "sense of justice", the interminable conflict between conscience and animal desire, or the criminal trial as a vicarious avenute of emotional release which supports the delicate balance of adjustment to social restraint. It is one thing to damn such emotional need and to look for a wiser direction of it; nonetheless it must be recognized that the present form of criminal procedure does take it into account in appreciable degree. Revision pointed not at Utopia but at the immediate future must make provision for such phenomena as well as for the other social functions of criminal procedure.

It is in the context of the above general functions and objectives of American criminal procedure that the present Revision must be placed. In the light of understanding of the basic problems, the specific needs and objectives of the current project become significant. These more immediate problems are numerous. Indeed, concerning the law of federal criminal procedure, it is almost possible to say there is none; that what is required is provision not revision. Certainly there is nothing approaching inclusive statutory law. The rules are scattered through the Constitution, the Revised Statutes, the Judicial and Penal Codes, and the decisions. The enactments are partial; they deal with special offenses and segments of the procedure. Obviously some over-all hypothesis of general procedural law was essential to the functioning of the federal system; in large measure this was supplied by "the common law" and by the common law of the states as of 1789 . Nonetheless many divergencies exist. Some federal courts do not follow state procedure, as in New York (until 1936) where the names of witnesses are not written on 
indictments. Uncertainties abound: the procedure on standing mute to an information, the requirements for issuance of search warrants, the plea in abatement which has developed sufficient technicalities to warm the hearts of even the sons of Zeruiah, the special plea in bar which must be carefully distinguished, and the like as regards demurrer and motion to quash. In light of the utter inadequacy of the statutory law, it is not surprising that the adoption by judicial decision of such major procedural changes as waiver of jury and testimony of husband and wife, setting aside many years of precedent to the contrary, provoled no criticism. What is rather surprising is the excellent standard of performance consistently maintained in federal criminal administration, revealing what can be accomplished by a highly competent persomel with grossly inadequate instruments.

\section{"Procedure" and "Substance"}

An initial difficult task for Revision is determination of the limits of "procedure". It is impossible here to analyze the relevant case-law, but we may indicate some of the chief aspects of the problem.

Recent emphasis on "function" has tended to stress a point of view from which all law may be regarded as "procedural". Certainly all law is "procedural" in the sense of commanding conduct, of having significance for action. So, also, it is clear that without remedy and procedure, legal rights would have little, if any, practical utility. Hence it has been argued that "the distinction between substantive and procedural law is artificial and illusory. In essence, there is none." 15 But such insights as these must not obscure the facts that there are important meanings with reference to which significant differences must be drawn, and that, especially from a precise functional point of view, formulated in terms of the variety of jobs to be done, it is essential to distinguish "substance" from "procedure". Generalization about "substance" and "procedure" is, of course, hazardous because of the variety of usage and function of ideas subsumed under each of these terms. The common differentiation is misleading chiefly in suggesting the lesser importance of "procedure". But if we recall constitutional and other basic guarantees, it is obvious that much more than "mere instrument" is included in "procedure". Even as to those procedural rules that serve purely lngical functions in governing argument, it is apparent that they contribute

15. I Chamberlayne, Evidence (1911) $\$ 171$. This point of view has been stressed by Professor W. W. Cook who has argued that "procedure" is not a fixed entity, that the term is variously employed, that particular purposes determine differentiation listween "procedure" and "substance" and that the chief objectives have been uniformity, cansenience and fairness. Cook, "Substance" and "Procedure" in the Conflict of Laa's (1933) 42 Yale L. J. 333. The latest article, which refers to much of the general literature on the problem, is Kocourek, Substance and Procedure (1941) 10 Fondmas L. Rxy. 157. 
substantially to the nature of the decision, since we seek rational decisions and rationality is determined by the methods employed. These considerations qualify the following analysis.

In the context of the total legal system certain rules (procedure) are described as "adjective" or "subordinate", or "merely instrumental" to other rules (substantive law). These terms are relative and formal rather than real. For substantive law may itself be viewed as merely a means to ends set by ethical and other non-legal criteria, such as deterrence, incapacitation, reformation, and the subsumption of these under "prevention". But crime prevention may also be regarded as but a means to an ideal of human relations, a means ultimately to "the good life." Clearly means and ends may continue thus in indefinite progression until all is subsumed under a generalization so broad as to include the heart's desire. Despite insistence on rigorous separation of ethical principles from positive law and the artificiality of actual separation of "means" and "ends" as regards the process of decision, it is permissible, indeed, necessary for some purposes to regard a legal system as including within itself various stipulations as to ends; and, therefore, within that system, to make distinctions relative thereto. Within these limits, the most fundamental distinction is that between rules that serve as ends and those that are instruments to the attainment of these ends. ${ }^{10}$ "Procedure" includes all those rules that prescribe the methods required to achieve whatever ends are legally "given". In this approach we accept the existing legal system "as is" as regards interests presently protected, and as regards the philosophy implicit in the existing law. The "concretization" of the substantive norm applicable in any given case occurs within a varying extent of choices. And we have only to consider the dependence of this choice (the particular content of the finally "discovered" st1bstantive rule) upon, and its relation to, the methods employed to "discover" it, to recognize the inaptness of considering the latter stbordinate, merely adjective, in any other than a formal sense.

The end-fixing rules, designated "substantive", are prescriptions expressed in terms denoting circumstances or hypotheses, on the one hand, and consequences or sanctions, on the other. These rules signify that on the occurrence of the described facts certain other facts must be applied - in criminal law, treatment or punishment. They also designate the values protected and implemented by the legal system. These rules operate caliper-like; from the whole buzzing welter of reality, they mark out particular segments, thereafter "legally significant", the "ends" of the legal system. Why particular circumstances rather than others are selected, why particular penalties are applied, these are not our present concern. What does concern us here is first, that facts constituting

16. See 2 Bentham, Works (Bowring's ed، 1843) 5. 
hypotheses or circumstances do not announce themselves, but must be "found"; and secondly, that "finding" the facts has meaning only by reference to end-fixing, "substantive" penal laws. Not because it is descriptive of actual psychological processes or their chronulogy, but rather because it suits the convenience of analysis and the modern habit of thought do we think of substantive law as pre-existing. What is wanted is an authoritative rational judgment that particular facts are included within the circumstances described in laws; it is the special job of "procedure" to regulate the process of providing such decisions.

The specific character of rules of procedure can be more sharply indicated by considering that they are similar to "technical" rules, i.c., as stating methods necessary to arrive at desired goals. But rules of procedure also partake of the character of all law in that they, too, are normative. Hence their necessity is not identical with that of rules, c.g., of bridge-building. ${ }^{17}$ The kinship of procedure and teclunical rules may be further perceived, if we recall that rules of procedure do not include sanctions for their violation, as do substantive rules. If counsel omits to demur to a substantially defective indictment, he simply fails to achieve the desired end. The rules of procedure do not impose legal obligations as do substantive rules. The effect, "sanction", is simply that the litigant cannot possibly arrive at the desired destination. Failure to plead correctly may, of course, form the hypothesis of a rule of tort law, but it is violation of that substantive rule, imposing a duty to exercise due care, that gives rise to damages, not any sanction attached to the rules of procedure themselves.

These distinctions, instrument from end, technical rules from norms that include sanctions, seem clear, but the difficulties of application may be illustrated by reference to "arrest". "Arrest" is included in authoritative analyses of criminal procedure from Hale to the Code of the American Law Institute. Obviously if we focus on the practical end of punishing offenders, we must certainly apprehend them, and arrest is merely instrumental thereto. But if the end is judicial decision, the presence of the defendant is not a logical prerequisite. ${ }^{18}$ Salmond limits procedure to "that branch of the law which governs the process of litigation," ${ }^{19}$ and this clearly excludes the law of arrest. Again it is apparent that in tort law "arrest" has quite a different significance. The rules mean there, that under prescribed conditions an officer is "privileged" to apprehend, which is equivalent to asserting that he is excepted from

17. Compare the observation that "procedure" should be distinguished from "law". Thayer, A Prelininary Treatise on Evidexce (1898) 193.

18. In a number of states, the defendant may waive this right and he does so if he voluntarily absents himself. Mirss. Cone ANN. (1930) \$1270; Orro Geni. Conz Arst. (Page, 1937) §13442-10; so also in Arkansas, Canada and New Zealand.

19. JURISPRUDENCE (7th ed. 1924) 495-96. 
the general duty to refrain from conduct designated "assault" and "in1prisonment". The nature and significance of these rules on arrest can therefore be comprehended only when they are viewed as qualifiers of the normal substantive rules. Thus considered, they are themselves rules of substantive law since, it is apparent, it is for convenience and simplicity only that the total relevant substantive law is stated in separate propositions.

Accordingly, with reference to whether "arrest" is "procedurc" or "substance", we find not only the necessity to distinguish some of the rules on arrest from others, but, also, even after this restriction of the relevant area, we find tradition and practical objectives pointed in one direction, logic in the opposite. There are still other difficulties. So far as the current undertaking is concerned, it must be anticipated that the courts will cleave rather closely to "procedure" as limited to the regulation of the trial, and that, within these limits, they will be further restrained not only by the safeguards imposed by the Constitution and Bill of Rights but also by case-law interpreting the ex post facto gutarantee to the effect that the defendant must not be deprived of any "stubstantial" right, including changes in procedure that operate to his disadvantage..$^{20}$ Theoretically this limitation on ex post facto laws should not affect other legislation; a potential area would be available - st1bstantial changes that do not violate constitutional guarantees. There are numerous difficulties, whichever path is taken. In view of the conditions of the rule-making, it is likely that the standard of "substantial disadvantage" will be extended generally. But almost any change in procedur'c may threaten the present allocation of advantage, c.g., selection of the jury by the court with consequent elimination of counsel's preliminary suggestions. The existing decisions provide little aid in application of this vague test. They merely suggest that "procedure" will be rigorously limited to the more technical problems of regulating the trial. ${ }^{21}$ No cloubt the courts will be especially anxious to impose no disadvantage on defendants in criminal cases, and will interpret "procedure" accordingly. It is obvious that questions of policy are here involved and that decisions will be made that rest only partially on legal doctrine. Provision of a greater range of choice, however, would not be diminished in ultinate utility by the fact that only part of the program is adopted by one branch of the government initially.

20. See McAllister, Ex Post Facto Laws in the Supreme Court of the Unitcd Statcs in 2 Selected Essays on Constitutional Law (1938) 1351, 1355-60.

21. With reference to the new Federal Rules of Civil Procedure, it has becu held that the burden of proof is "substance." Cities Service Oil Co. v. Dunlap, 308 U. S. 208, 212 (1939); and a district court dismissed a complaint for failure to allege freedom from contributory negligence. Francis v. Humphrey, 25 F. Supp. 1 (E. D. I11. 1938). 
Problemis Suggested by the New Rules on Civil Procedure

The new Rules of Civil Procedure are among the most impurtant reforms in our legal history. There is much to be learned from that undertaking as regards organization of the present work, the conduct and criticism of proposals, the public debate and publicity su effectively maintained. One objective of the new rules was uniformity; there is no reason for questioning the like for criminal procedure. Federal criminal procedure is not governed by the Conformity Act as was the civil; the difficulties and divergencies in practice are no less numerous for reasons noted above. Since the crossing of state lines is cummunplace, uniformity would lessen the burdens imposed on bar and judiciary. Final appraisal obviously rests on the quality of the procedure that is urged for general adoption; there is no merit in uniformity apart from that.

There are many provisions in the new rules which can be clusely applied to criminal procedure, such as abolition of the demurrer and various special pleas, elimination of restrictions on time previously imposed by expiration of court terms, provision for free amendment (that would need to be limited as regards indictments), the order of jurisdictional defenses, the abolition of bills of exceptions and of the taking of formal exception to rulings by the court, and the official forms. In general, as regards the purely technical rules, those that are neutral as to advantage, the new civil rules are always suggestive and sometimes can be applied almost literally to criminal procedure. The great prestige of private law and of the new rules, their wide acceptance and their merits will also suggest very strongly the adoption of their major specific reforms which would seem to constitute the areas of greatest promise. Consequently the suggested application of these reforms to criminal procedure will require the most careful consideration and the maximum technical knowledge.

Among the most important of these reforms in the new rules ${ }^{22}$ are the provisions for joinder, pre-trial conference and discovery. As regards joinder, the underlying policy of the new rules is certainly sound: the settlement at one time of all controversies between all parties whose disputes involve common questions of law and fact. By comparison the rules of criminal procedure on joinder seem primitive. They are vague and variant. The civil rules stimulate to discovery of the relevance of, at least, their general principles. It is apparent, at the outset, that the civil rules necessarily have a far greater range because they may include any number of parties with claims and counterclaims against each other, whereas in the criminal law, the process is much simpler; there is not

22. See Clark, The Proposed Fideral Rules of Cizil Procedure (1936) 23 A. B. A. J. 447. 
only a single party bringing the action, but also, the interests of all defendants, however numerous, run solely against that one party, not against each other. In addition, the field of private law is quantitatively much larger and more diverse. Hence the utility of the identical provision for joinder is narrowed considerably in the criminal law. But the lessened potentialities should not dull the desire to advance the principle as far as desirable. At the very least, thorough analysis of the analogous problems in criminal procedure would greatly clarify this presently most confused of all its areas. Much more may be possible. It is difficult to generalize regarding the problems resulting from the presently very diverse rules and practices. They arise from: (1) joinder * of counts is rigorously limited to cognate offenses, (2) the notion of "transaction" has been of little aid to joinder because of insistence on the preceding limitation or on a common mode of trial, (3) separation of parties and trials is required where there is likelihood of prejudice, and as regards co-defendants in a criminal case, the possibility of prejudice is great and (4) the joinder of indictments has been restricted to cases of practically identical proof throughout. It is impossible here to discuss the reasons adduced for such rigorous separation of counts, indictments and trials; they include confounding the accused, prejudicing him in his challenges, suggesting that he is an habitual criminal, confusing the jury, and others. ${ }^{23}$

The most fruitful single avenue of attack upon the above problems would seem to be implementation of "transaction" so far as the orbit of criminal behavior is concerned. In this regard it may be noted that present procedure, though quite restrictive as to joinder of counts or indictments, ranges widely as concerns admission of evidence of other crimes tending to establish the commission of the one charged ${ }^{24}$ If these rules are valid, it would seem proper, and in any event, it is certainly logical, to present a complete picture of the defendant's criminal behavior rather than a severely isolated segment of it. In fact, criminal behavior, especially of professionals, normally occurs not in isolated events but in series of transactions. Thus, in the business of dealing in stolen bonds, the behavior of a group of persons may include conduct that constitutes larceny, burglary, robbery, false pretenses, forgery, receiving stolen property, transportation across state lines, possession of stolen securities and other offenses. The murder of a bank guard may have been immediately preceded by robbery or burglary, theft of an automobile, carrying concealed weapons. Present reliance upon a conspiracy count is limited, opportunistic and frequently unfair. The logic of the facts argues for far greater flexibility of criminal pleading along lines sug-

23. See McElroy v. United States, 164 U. S. 76 (1896).

24. See (1931) 29 MIICH. L. Rev. 473. 
gested by the new civil rules, and by the rules of evidence. No hardship need result from the fact that different modes of trial are usually required on the basis of gravity of offense, since the one prescribed for the major crime charged could be had for all, and this presumably offers greatest protection of the defendant's rights.

The major difficulties result from the fact that criminal trials differ markedly from civil ones. In civil litigation personal prejudice is a minor affair, but in criminal prosecutions there must be constant vigilance that an accused is not convicted simply because he is a notorious person, or because he has a record, or has dealt with criminals, or by allegation of numerous offenses, no one of which can be proved beyond reasonable doubt. Again, in civil law every single obligation is important; if a corporation owes $\$ 1,000,000$ but has a counterclaim for ten cents, that should be taken into account. On the other hand, in criminal law, not only is it impracticable to prosecute for every crime committed by an individual, it would be unnecessary to do so in some instances, absurd in others. A convict pays with his life - at a more or less accelerated speed and he has only a particular limited expectancy; the utility of piling up a criminal record beyond possibility of significance for him is quite a different affair from its logical civil counterpart. The practice is to convict on the maximum charge possible, and to ignore the rest except for purposes of fixing sentence and determining parole. Finally, in civil cases the litigants incur expenses, and their time is valuable. These are incentives not only to compromise and continue decent relations, but also to take a strictly economic appraisal of the litigation. The matter is utterly different in the vast majority of prosecutions where the defendants have nothing to gain or to lose - except life or liberty. Especially in cases where persons of affluence are defendants, the saving of expenses is a minor affair as compared with conviction or imprisonment.

These factors apply also to discovery before trial with the added possibility of abuse on both sides; on the one, the temptation to indict first and get the proof later $;^{25}$ on the other, to secure information to perfect improper defenses. Finally, as to pre-trial conferences, it must be noted that the need here is not nearly so great as in civil litigation because in the criminal law the preliminary hearing has traditionally served to check irresponsible accusation. ${ }^{20}$ Pre-trial conference may have

25. "But I have known rich men whose characters were ruined by unwarranted indictments under which they were never convicted, and I have known others who spent their every dollar and beggared their families defending indictments which should never have been found." Black, The Progress of a Criminal Case in 7 Lectunes 0: LFriv. TopICs (1929) 339, 345.

26. Compare "This wasteful method of [private] litigation was perhaps the more remarkable because criminal procedure provided a very effective means for promptly eliminating apparent controversies which had no merit" Sunderland, Theory and Prottice of Pre-Trial Procedure (1937) 21 J. Axr. Jun. Soc 125. 
value in certain federal prosecutions, and the limited use of the preliminary hearing in federal procedure certainly argues for some provision in that regard. But it will be noted that in the instances of its use, recently reported, the defendants' stipulations resulted in suspended sentences. ${ }^{27}$ In view of the fact that such conferences are commonly held between prosecutor and defense counsel and that the prosecutor is in a rather different position than counsel for a private litigant, the above use of pre-trial conference suggests that compromise is the only additional advantage, i.e., compromise beyond what the prosecttor thinks necessary. But in criminal proceedings, compromise (except in a few minor offenses) is, at best, a practical necessity, ${ }^{28}$ not a proper end, in itself.

Since the basic objectives of criminal law differ radically from those of private law, reforms that are essential to the one may be irrelevant to or even harmful in the other. Criminal law is ultimately concerned with judgments that have moral significance and that are implemented by the imposition of punishment. Hence many procedures that are logical and worthy, judged by other standards, fall far short of the mark in this field. Only detailed studies of the suggested provisions and of the rules, practices, actual conditions, distinctive problems and objectives of criminal prosecutions can provide the knowledge required to determine how far, if at all, the above reforms are applicable to criminal procedure.

A major problem for Revision, indeed for law-making of any kind, that is only very generally suggested by the new rules, concerns the form of the total product of the undertaking. The new Rules of Civil Procedure are not complete in themselves but it is possible that everything feasible in that field was provided. The present condition of federal criminal procedure requires legislation that is inclusive and complete, rather than complementary and fragmentary. The need for brevity requires the writer to state his conclusions in this regard with little effort to develop the antecedent steps. In the writer's view the end-product should be a code of federal criminal procedure. A code, in contrast to statutes, will be relatively complete, offering little occasion to look elsewhere to fill lacunae - except as to constitutional provisions, where the total existing body of decisions will continue to define them, and will be augmented as in the past. Secondly, a code will be completely organized along lines suggested by logic, chronology and subject-matter, so that the various provisions are readily accessible. But the major benefit 120.

27. Way, New Technique Facilitates Criminal Trials (1941) 25 J. An. Jud. Soc.

28. The expansion of the use of summons for directions in England in 1932 did not include torts based on fraud or malice, false imprisonment or seduction. See Sunderland, $o p$. cit. stipra note 26, at 128 . 
will be the aid rendered interpretation, the day-to-day work of lawyers and courts; the ultimate criticism of the end-product of Revision must surely include its utility in the judicial process. Any judgment in this regard must rest upon a broad base that includes appreciation of the erer-mounting volume of case-law and the consequent difficulties both practical and theoretic that perplex the common lawyer; it must include some sophistication concerning the actual civilian judicial process as contrasted with its character a century ago or that provided in the literary versions of its apologists; and it must result from a careful consideration of the special problems of criminal procedure.

Flexibility of common law has been extolled as against an alleged rigidity of code law, but it is a serious question whether "Hexibility" does not now threaten to become a mere euphemism to cluak completely "free decision." We cannot elaborate the issues here nor their general significance for the private law. What is axiomatic in the field of crime, assuming the preservation of American traditions, is that officials must be rigorously limited as regards the major guarantees provided by criminal procedure. The choice actually presented may be one between evils; however, if the vagueness of present federal criminal procedure provides such flexibility as almost to eliminate restrictions on official judgment, then, at least, we encounter no new danger in this regard if we turn to a code.

There are several reasons for believing that a code will function more effectively in the field of criminal procedure than in many others. It has been generally recognized that codes have been more widely used in public law than in private; and even Carter conceded that as to "the procedure of courts of justice. . . . it is important that this should be regulated by written rules framed beforchand. . . "2s The present project, incorporating both public and procedural law, would therefrire seem especially propitious for codification. Moreover, procedure as usually defined is concerned with a rigorously restricted segment of reality chiefly certain occurrences within a courtroom. The significant categories are few, and the job of standardization is relatively simple. Finally, these rules are addressed almost exclusively to professionals. Greatur competence, uniform training, and knowledge of technical terms would facilitate the successful operation of a code of criminal procedure.

The danger of perpetuating the common law bias in statutory interpretation is lessened, the likelihood of creating new psychological attitudes and habits is greater if a code is provided. It must be recognized. of course, that the problems of language, interpretation and application

29. Carter. The Proposen Codrfication of Our Common Law (18\%t) 19. He anticipated the present reform by urging that: "The true wislom in relation to this sulject is to deal with it in a way which affords the advantages of statutury law withuut its evils: and that is to entrust it to the courts to irame rules fur its regulation." Ilibl. 
are perennial and common to all legal systems, and that no code would actually be complete and adequate except for a brief period, since human prescience is limited and external change is constant. Sound revision, seeking better methods, not Utopian simplicity, will indulge in no denials of the persisting complexity of any enlightened judicial process. But much, it is submitted, can be accomplished by codification, supplemented by provision for periodical inventories and critical appraisals of the code in light of subsequent case-law, and for periodic amendment in light of new needs, ideas and preferences. Although the code would not include the commentaries of the revisionists, these would be published simultaneously, illustrated by specific decisions. The preparation of these commentaries is no less difficult than it is essential. It is difficult because it calls for examination and critical appraisal of the total body of relevant case-law, at least in all the states and federal districts, as well as for the additional researches described below. It is essential to improved adjudication because it makes readily accessible helpful commentaries on and authoritative résumés of the case-law.

In the past, the basic difficulty with codification has been the actual inadequacy of codes and commentaries which no amount of exhortation has concealed. A degree of rigidity is endured, but a saturation point is reached inevitably and courts have taken the obvious necessary steps - despite code and despite commentary. But it must be recognized that social change and need constituted only one side of the formula; the other phase of the problem was posed by the traditional diffictlties in the way of amendment of the law. The outstanding merit of the new legislation on rules of procedure is provision for continuous and deliberate law-making in this field. In the polarity of law and society, we may take "society" as given, as denoting institutional changes that confront us and challenge existing ways of control. The most developed instrument of control is provided by the legal apparatus; if we can set up competent agencies to study and reform the laws, we avoid the need for circumvention via concealed judicial legislation - at least normally and as regards major changes. We provide for flexibility of the code, and meet the major criticism levelled at all efforts to advance codification. Accordingly it must be stressed that a basic corollary of codification is periodic revision.

An integral part of codification, indeed of any legislation, is the language problem. It is necessary to supplement the remarks above on pleading by considering briefly the current emphasis on simplicity, precision and the like. Certainly any simplification that results from modernization of vocabulary is a worthy objective. In large part, the present terminology is a vestige of literal translation of Latin phrases, e.g., force and arms, breaking close, malice aforethought. Although many of 
these linguistic archaisms are warp and woof of substantive law, necessary linguistic reform might well begin with procedure even though the terms employed would require translation into the sulstantive traditionalisms, pending like reform of the latter. On the other hand, the language problem includes much more than modernization of terms. For, it is apparent, the common statement of objectives, "clarity", "simplicity", "precision" and the like, masks rather than explains the problems. "Simplicity" suggests elimination of unnecessary technicality - but "necessity" is not obviously or automatically determined. "Clarity" arguts for elimination of indefiniteness; and "precision" for univocal, not ambiguous, provisions. But all such characterizations are mere symbols if generalities, themselves too vague to be clear or precise. They have nu greater utility than any number of similar slogans which are unexceptionable only because they are vague.

In the older eras of codification. to cite a specific instance, it was assumed that a catalogue of "definitions" would simplify, clarify, cte. But experience has demonstrated the elusive nature of such simplification and that though a few definitions occasionally help, the desired ends can only be attained in part, by consistent use of the terms throughout the code. This formal phase of the problem is relatively simple. The much more difficult aspect is semantical; what we are chiefly concerned with is the accurate consistent reference of terms to substantially similar situations. To facilitate this objective would require a terminology constructed on the ample experience of past decisions where ambiguities and inconsistencies could be discovered. Beyond that it is evident that if we have learned anything at all about "clearness", "simplicity" and the like, it is that the simplest provisions are apt to be the most ambiguous, that superficial "clarity" is most frequently confusing. The unexpressed premise in such pretension is wide discretion, a function of paramount concern in the criminal law. Such provision may be the best available regarding those phases of procedure that defy precise formulation beforehand; in the alternative, it is evident that such "solution" simply begs the problem, passing the powers and the difficulties on to the bench. A series of narrow rules may serve the desired ends better than a few blanket generalities. We confront here the recurring conflict between technicality and common sense. Whatever the desirability of sweeping provisions for private litigation. the student of recent developments in criminal law will cherish a wholesome skepticism concerning pretensions to attainment of "substantial justice" in criminal cases at the cost of precise accusation and specific, known procedures. We should keep in mind that, in this context, common sense procedure means, finally, enlarged discretion of the trial judge; we must proceed accordingly in light of the basic objectives of the criminal law. If Revision is fore- 
warned against the superficial simplicity and clarity of indiscriminate generalizations, it may draw upon careful studies of case-law and practice to implement the desired ends by provisions whose precision and clearness can be defended in light of reason and experience.

\section{CONCLUSTON}

Judicial rule-making has the rare advantage of juxtaposing knowledge of procedure and legislation. It thus represents a notable advance in the direction of reforms advocated by Bentham and Livingston, and that now familiarly known as a Ministry of Justice. It may provide a well-founded answer to the alleged inflexibility of coles. It is obviously' one solution to legislative indifference in the procedural field. On the other hand, it must be recognized that serious questions arise from the possession of the rule-making power by the courts, and that serious limitations are imposed on revision, if narrowly conceived. The reforms, long advocated, which sought to bridge the gap between courts and legislature did not contemplate law-making by the courts. ${ }^{30}$ Whether the new arrangement represents merely a partial, temporary advance which needs correction in the direction of the English Rules Committee with ultimate resort to the legislature cannot be discussed here, althougl, it may be remarked, it is rather curious that scholars who have strenuously opposed recent trends towards centralization in administration are among the enthusiasts for judicial rule-making - a position that may be defensible on practical grounds of difference in personnel, training and tradition, certainly not on principle. For it must not be forgotten that as the result of the present delegation of power, the same branch of government that makes the rules, interprets, applies and amends them. Some of the implications of such concentration of power in the field of criminal law have been noted above. What must be stressed in conclusion is that the present revisionists must fully confront the likelihood of jtclicial unwillingness to institute changes that will impose any serious disad vantage on either state or accused, that the project will be rigorously confined to clarification of the existing procedure. If the objective is thus narrowed, a critical appraisal of the Code of the American Law Institute may suffice. ${ }^{31}$ It is submitted, however, that the effort should be to integrate the practical job in a broadly conceived program which will not only assist the court in immediate needs, but will also clelineate the areas for further investigation irrespective of present limitations.

30. See 11 Benthas, Works (Bowring's ed. 1843) 35, 36; 1 Livingston, Comilatre Works on CRIMINal JuRisprudence (1873) 415.

31. The greatest limitation on the utility of the Institute Code for this purpose is that the "Commentaries" do not state the reasons in support of the rules adopted but are simply digests of the decisions. 
Full advantage should be taken of a rare opportunity to plumb the basic problems of criminal procedure and, at least, to initiate a thoroughgoing program for continuing study and progressive reform. For beyond the immediate task loom the more permanent objectives of Revision - increased insight into the most effective methods of research in criminal procedure, the discovery and careful formulation of standards of criticism, knowledge of the functioning of the rules in actual administration, and of the procedure of foreign systems and in specialized areas, as well as provision for periodic amendment. There is no conflict between immediate and permanent ends; on the contrary the value of the current project will depend in large measure upon its orientation and progress in the broader context of basic objectives. 